\title{
Correction to: Developing Critical Reflection Practices via Reflective Writing for Pre-service Language Teachers
}

\section{Correction to:}

Chapter 7 in: Kenan Dikilitaş, Ali Bostancıoğlu, Inquiry and Research Skills for Language Teachers, https://doi.org/10.1007/978-3-030-21137-0_7

The online version of the original chapter was inadvertently published with incorrect author names. The names have been corrected as below:

Kenan Dikilitas and Ali Bostancioglu

Changed to: Erdem Akbaş and Kenan Dikilitaş 